executive of one of our important health departments, information upon the incidence of tuberculosis in his state for the past decade. In his reply he stated, among other things, that recently there had been a very marked and quite inexplainable decline in the tubereulosis death rate. The statement struck me as singular, for it is difficult to conceive of a sudden, conspicuous decline in the death rate of a dis. ease of the nature of tuberculosis, without a reasonable explanation for it. A very brief search for an explanation soon revealed the fact that the experience of the particular health officer to whom I had written was not peculiar to his state, but was demonstrable for: practically all our registration states, as well as for the most of our larger centers of urban population.

If one will chart by years the mortality rates for tuberculosis for a period covering the past fifteen or twenty years, for almost any of our states or cities that keep correct records and that have been active in the suppression of tuberculosis, it will be seen that in the main there was a steady decline until 1917 and 1918. During 1918 and 1919 there was a sharp upward trend to the curve, followed in a year, or at most two years, by a marked downward direction of the curve-much steeper in its descent than that preceding 1917-1918. With a number of such charts before one, the reason for the recent decrease in the death rates from tuberculosis becomes obvious. The pandemic of influenza of 1918-19 carried off, in a brief period, a large number of tuberculosis subjects that would otherwise have lived on and their deaths been so distributed through later years as not materially to have disturbed the uniform. downward direction of the tuberculosis curve that preceded the period of the great pandemic.

From the standpoint of results, advantageous to the race alone, and disregarding all humane considerations, this may be viewed as the beneficent influence of a great plague. The least resistant of the population succumbed, those more resistant and physically better fitted to survive, did so. The human material thus left is probably the most promising that has existed for generations, in so far as the permanent lessening of tuberculosis among it is concerned; and we can expect that the curve for tuberculosis death rates in the future will be for a time much more sharply downward than ever before, and that its average level for a number of coming jears will be much lower than that preceding the epidemic of influenza, providing, of course, there is no abatement of those widespread activities that have been so instrumental in lessening the incidence of the disease in the past.

For the anti-tuberculosis worker, the present appears to offer a golden opportunity.

A. C. Аввотт

School ow Hyatene and Public Health, Univtrastey of Pennsylvania

\section{OLD GLACIATION IN THE CORDILLERAN REGION}

To the EDItor of ScIence: The communication by Thomas Large on the above subject in the September 22 issue of SCIENCE prompts me to write that in 1916 I found till with striated boulders and pebbles in the brickyard near the normal school at Cheney, Washington, beyond the limits here reported by Large. I brought this matter to the notice of the Geological Society of America at the Albany meeting in December, 1916, and the following brief statement concerning it appears in the proceedings of that meeting (Bull. Geol. Soc. America, Vol. 28, p. 143) :

In northern Washington the occurrence of a very old drift, probably Kansas, was established by the discovery of till and striated stones on a high divide southwest of Spokane, in the vicinity of Cheney. Boulders had been observed in this region, and the possibility of glaciation had been suggested by M. R. Campbell in the Northern Pacific Guide Book.

Frank LeveretT

AnN ARbor, Michigan, SEPTEMBER 25, 1922

\section{SOME SIMILARITIES BETWEEN THE GEOL- OGY OF CALIFORNIA AND PARTS OF THE DUTCH EAST INDIES}

If we compare the Sierra Nevada with the Malay Peninsula, the Coast Range with the Barissan Mountains of West Sumatra and the great valley of California with the plains of East-Sumatra, it is obvious that the topograph- 